\title{
THE DIATOPIC VARIANTS CUSCO, ZAINO, CHIRU AND ILHÉU IN BRAZILIAN PORTUGUESE
}

\section{LAS VARIABLES DIATÓPICAS CUSCO, ZAINO, CHIRU E ILHÉU EN PORTUGUÉS BRASILEÑO}

\author{
Dayse Rodrigues dos Santos \\ Instituto Federal de Educação, Ciência e Tecnologia do Pará \\ dayse.rodrigues@ifpa.edu.br
}

\begin{abstract}
:
The diatopic variants of lexical level present in Brazilian Portuguese are present throughout the territory. Thus, the occurrences of common variants in southern Brazil were analyzed in the short stories Trezentas onças and Melancia - Coco verde from the work Contos gauchescos (1976), by João Simões Lopes Neto, in the light of variationist sociolinguistics and dialectology. The objective is to appreciate how the lexical items cusco, zaino, chiru and ilhéu converge in this type of linguistic variation in comparison with Brazilian Portuguese standard. After reviewing the bibliography on variationist sociolinguistics and dialectology, the most categorical passages were selected in which the four words appear to weave more in-depth reflections, performing the qualitative character of this research. As a result, we verify the way in which the southern literary language illustrated the dialect in this textual production.
\end{abstract}

Keywords: Brazilian Portuguese, dialectology, diatopic variation, lexicon.

\section{Resumen:}

Las variantes diatópicas de nivel léxico presentes en el portugués brasileño están presentes en todo el territorio. Así, las ocurrencias de variantes comunes en el sur de Brasil fueron analizadas en los cuentos Trezentas onças y Melancia - Coco verde de la obra Contos gauchescos (1976), de João Simões Lopes Neto, a la luz de la sociolinguística y dialectología variacionista. El objetivo es apreciar cómo los ítems léxicos cusco, zaino, chiru y ilhéu convergen en este tipo de variación lingüística en comparación con la variación estándar del portugués brasileño. Tras revisar la bibliografía sobre sociolingüística y dialectología variacionista, se seleccionaron los pasajes más categóricos en los que las cuatro palabras parecen tejer reflexiones más profundas, realizando el carácter cualitativo de esta investigación. Como resultado, comprobamos la forma en que la lengua literaria sureña ilustró el dialecto en esta producción textual.

Palabras clave: Portugués brasileño, dialectología, variación diatópica, léxico.

Recibido: 02 de marzo de 2021

Aceptado: 09 de junio de 2021 


\section{Introduction}

With large geographical dimensions, Brazil includes linguistic characteristics that vary considerably across its territory. Even so, Brazilian Portuguese speakers, henceforth BP, even if they do not know the meaning of a specific word when talking to a speaker coming from a more distant region, do not interpret it as being a foreign word or expression. Consequently, it is possible to detect lexical differences between what is said in the south and in Brazil north, without this necessarily preventing or making national communication unfeasible. In this study, the theme of diatopic variation is explored, based on sociolinguistics theory, in Contos gauchescos (1976), by João Simões Lopes Neto, one of the most representative literature books of both this author and national production as a whole.

The book is a narrative collection, containing 19 stories set in the state of Rio Grande do Sul, released in 1912 and reissued several times and decades later. The general objective is to analyze the occurrences of the cusco, zaino, chiru and ilhé $u^{1}$ variants in the tales Trezentas onças and Melancia - Coco verde, very known by locals, so that it is possible to understand these variants can impact the overall understanding of the text, without being replaced by the respective terms of the BP pattern. That is, understanding how variants are regulated by the tales.

To this end, some relevant aspects of the author's life and work will be briefly taken up, in order to situate cultural issues in his writing and justify why his texts were chosen. In the following section, the theoretical assumptions that support this study will be present in a way that can support and resolve the proposed notes and reflections. It is also important to say that this author and his respective books are widely known by people from Rio Grande do Sul, so that one may understand why his work draws attention.

The aim of valuing regional variants goes beyond the simplistic view that they are exotic and unusual lexical items. Whether they are diatopic or regional variations, especially Brazilian southern ones, they have been used in literature, podcasts or humorous programs, however, always with a connotative and precious sense, in face of the standard BP to show linguistic

\footnotetext{
${ }^{1}$ Since these are geographical variants from the state of Rio Grande do Sul, Brazil, it was decided to allow Portuguese language terms to maintain the linguistic particularities of that region. It is worth mentioning that these lexical items do not find equivalents in English, which can be used in this research situation.
} 
differences. It is very usual in Brazil to evidence a typical accent to highlight regional identities. Thus, Maria Aragão's clamor is invoked when she says that "the so-called nonstandard dialect must be valued on the same footing as the standard dialect"2 (Aragon 40). This way, the nouns cusco, chiru and zaino can be listened to by locals in current communications, lyrics or poems. Notwithstanding, ilhéu adjective is the most uncommon among them, inclusive it is difficult even for Brazilian from other regions to understand its meaning. That is why these four words were chosen at the expense of the dozen others which appear in Lopes Neto literature: because they represent words from common to rare in South vocabulary through decades till now.

The methodology is summarized in bibliographic research in theoretical books, online dictionaries and scientific articles on the subject. In order to structure this article, the body of the text was divided into three parts: the first section deals with the life and work of the author João Simões Lopes Neto and its relations with the context of his literary production; the second section presents a theoretical overview of variationist sociolinguistics and diatopic variation to support the analysis of the four terms in the two stories; the third offers a more in-depth analysis of the terms cusco, zaino, chiru and ilhéu, in each of the stories, Trezentas onças and Melancia - Coco verde, so that it meets the this study objectives.

\section{Simões Lopes Neto: life and production}

Simões Lopes Neto, as he was better known, was born and died in Pelotas, state of Rio Grande do Sul, was from a family of ranchers, studied in Rio de Janeiro, but was not rich. Only during childhood had contact with country life. In 1886, he returned to Pelotas, leading an essentially urban life. His literary activity began in journalism, he was a writer, chronicler, editorialist and serialist. According to Luis Pereira (261), in his master's dissertation, the Peloton went through the theater with the pseudonym "Serafim Bemol", published Contos gauchescos (1912) and Lendas do Sul (1912), wrote about the reality he knew. The author's main character is Blau Nunes.

2 All citations are free translated by the author of this article. However, Lopes Neto's excerpts were not translated in body text to maintain the originality of his literature. Even so, footnotes were used to explain or translate them freely. 
I believe that his projects were not, in principle, exactly literary, but of an educational and civic character that, due to certain circumstances of the author's personal life, were transported to literature. [...] I believe that we can invoke several Simonian texts to try to discover (although without certainty or guarantees) which project the writer had and to what extent he managed to carry it out (Pereira 54-55).

His interest in rescuing the Brazilian south culture and the regionalist language used in his works lead one to believe that the author would make the "traditionalist gaúcho3" type, but his biographers claim that he never wore a bombacha and that his cultural habits were urban. Thus, it can be inferred that the author maintains a strong link with orality permeated by folk niches. Lopes Neto, also, was the author of the plays O boato (1894), Mixórdia (1894) and Viúva Pitorra (1898), but it was in 1912 that he published Contos gauchescos, a work that highlighted him as one of the greatest writers of literature in Rio Grande southern.

It is mandatory to elicit that he uses primarily regionalist language in order to maintain rudimentary aspects of the gaúcho's lexic. It does not mean that words studied in this article are not usual by his time or decades before it or even currently spoken by locals. It is interesting to note that even though the corpus is composed of two tales of Contos gauchescos, first released in 1912, it continues significantly for southern culture in a general way of seeing.

\section{SOCIOLINGUISTICS}

Sociolinguistics' main researcher, Willian Labov $(1966,1976,1978)$, drew attention to the social aspects of language when he studied social issues about/r/ uses in New York. His reflections about the relation between concrete situations of communication and what they mean to speakers introduced studies all over the world. Since then, many others have been dedicated to sociolinguistics as Giglioli (1972), Ferguson (1972), Bernstein (1972), Bagno (1997), Calvet (2002), Sá (2009) e Beline (2002)4. In this paper, the theoretical references are as closely related to diatopic variation in order to comply with its objectives.

\footnotetext{
${ }^{3}$ A person who was born in Rio Grande do Sul state, Brazil. There is not a possible translation which maintains the set of meanings of gaúcho or gaúcha words. It justifies the maintenance in Portuguese. ${ }^{4}$ These authors were cited as a reference of the Linguistics area. They are not necessarily mentioned so forth.
} 
The work Contos gauchescos (1976), by Simões Lopes Neto is considered one of the great literary productions of Rio Grande do Sul state. For this reason, it cannot fail to pay due value, also in the sociolinguistic aspect, since its regionalist content offers healthy content for such a study. In this way, diatopic variation will be approached, which is the study object of sociolinguistics, so that one can understand how it is approached in this work of Brazilian Literature.

For Edimilson Sá (Cit. In Sá 57), sociolinguistics argues that language receives variations, determinations and social values from the society that used it. The language also characterizes the culture of a people, it ends up acting in the formation of social and regional identity. In the same vein, it is found in José Teixeira's studies that "there are certain lexical variations that cannot be ignored or transformed into anathema, since they have a highly significant sociolinguistic presence" (Teixeira 06). Soon:

Standard and standard language have been understood to imply uniqueness. Thus, in this perspective, one easily falls into the methodology that if there are two variant lexical units, only one will be able to be normal and the other will have to be regionalism or provincialism (Teixeira 06).

Considering that sociolinguistics is a science that studies not only the language, but also the social level in which it is inserted, "the linguistic varieties found in the different ways of speaking have relevance both in the lexicon used and in the morphosyntax and phonology" (Sá 57). As an example, the following excerpt was extracted "looking at guaiaca and guaipeva, curled up at my feet." (Lopes Neto 15), which demonstrates the typical talk of the man from the gaúcho pampas. In this sense, it is up to sociolinguistics to understand how individuals print their linguistic particularities, depending on the region, age group, social level, among other issues in which the speakers find themselves.

That said, it is in the considerations of Ronald Beline (2003) that the guiding foundations of the theoretical discussion about linguistics and its subunits are found. For the researcher, the nature of sociolinguistic studies should include, among others, quantitative elements in order to better understand how variation is regulated in contexts. So,

this area of language science that seeks, basically, to verify how factors of linguistic and extralinguistic nature are correlated to the use of variants at different levels of the grammar of a language - phonetics, morphology and syntax - and also in its lexicon. From a quantitative variationist perspective, 
[...] sociolinguistics is concerned with unraveling how heterogeneity - that is, variation is organized (Beline 125).

In the perspective of the aforementioned author, there is a very substantial distinction for the analysis proposed in this article on the dialectical perspective. That is, "it is in the researcher's interest to check if speakers of the same language have differences in their ways of speaking according to the place they are in (diatopic variation)" (Beline125). Thus, this theoretical alignment is adopted to understand the way that cusco, zaino, chiru and ilhéu portray the lexicon of the southern region of Brazil, that is, how the characteristics of this dialect are represented in the gaúcho literature.

To study diatopics, it is necessary to ratify theoretical concepts including dialectology. This is because it is necessary to take into consideration "the type of variation that occurs, whether the phonetic-lexical and morphosyntactic variations, for example, are really regional, dialectal, in their specific sense or whether they are also social or sociolinguistic" (Aragon 36). Even so, this differentiation is fragile, since a given variant identity runs through both regional and social issues.

Therefore, when resuming these study objectives, we strive to locate and describe the four lexicons in the identified corpus, since linguistic awareness matters when using the terms cusco, zaino, chiru and ilhéu in the stories. In his doctoral thesis, Valter Romano states that it is possible to understand "that the lexical specificities of a given region are more conditioned to historical-cultural aspects than to geographic and political ones" (Romano138). In this way, we aim only at the lexical study of these terms, starting from the dialect concepts established by Romano:

the use of the term dialect refers to a set of isoglosses more or less coincident in a given territory. Thus, delimiting dialectal areas or the existence of dialects is only possible based on data of a lexical-semantic, phonetic-phonological, prosodic or even morphosyntactic nature that coincide in a given territory (Romano 98).

In this sense, Romano and Seabra declare that "diatopic variation, however, underlies the different types of variation $[. .$.$] because the individual is located in a certain geographical$ area, which also determines the linguistic variety he uses" (Romano and Seabra 62). Regarding the locality, "the geographical varieties are called regionalism, which characterize, among other aspects, the way of speaking the speakers of each region of a country” (Sá 57), 
that is, diatopic variation. We can see this type variants in the excerpt " $O$ chiru criou-se junto com os meninos 5 " (Lopes Neto 43), in which chiru replaces the term caboclo $^{6}$, more used in other regions of Brazil. It is worth remembering that the choice of a given lexicon also results from subject-speakers appreciation of that region, that is, using a regional variant instead of the standard variant contributes to marking the text's identity. According to Teixeira (17),

The notion and mechanisms of the standard have an important sociolinguistic function. It is not worth saying that scientifically all regionalisms and norms, even those of the variants, have the same linguistic dignity because the social stigma of the a-normal is in charge of expelling from the uses and language, sooner or later, what is connoted with less prestigious varieties (Teixeira 10).

Because it is a regionalist and even folkloric work, the language ends up challenging even Brazilian readers, since it is necessary to effectively use a dictionary of regional terms. Thus, "social conditions influence the way of speaking of individuals, generating certain variations in the way of using the same language" (Sá 55), which essentially characterizes the perception of this variant. Thus, diatopic variation becomes essential for this research. See another situation of diatopic variation through the following section of Watermelon green coconut, "Veio o vigário com o sancristão e gentama de toda parte"7 (Lopes Neto 43). The term sancristão is notably a transposition from speech to writing, since the dictionary form in the Portuguese language is sacristan and the term gentama refers to a large number of people, however, the use of this variant is not seen in other regions of Brazil.

The occurrences refer to the phenomenon in which a language, in current practice, changes in a time, place or social group, providing its object to historical grammar, linguistic geography and dialectology, as well as to social variation (Sá 57).

Evidently, the time when the text was written, 1912, cannot be ignored, since language not only takes place in a given space, it also varies over time, the diachronic variation. Still, there is variation between certain social groups, the diastratic variation, as occurs in the rural

\footnotetext{
5 Chiru was created along with the boys.

${ }^{6}$ Individuals born of Indian and white people (or vice versa), with copper skin and straight black hair, called here as Indian and white's sons.

7 The vicar came with the sacristan and people from everywhere.
} 
area of Rio Grande do Sul. The texts cited are narrated by Blau Nunes, who is also a character. The narrator uses the traditional language of Rio Grande do Sul from the 19th and 20th century. Blau Nunes' speech is suggestive, metaphorical and natural, as in "encilhei o zaino e montei"8 (Lopes Neto 12). In this case, we see the use of the term zaino to the detriment of the term horse in the short story Three hundred ounces. It is through the knowledge of the regional vocabulary that we see its deepening and better understand the linguistic uses of the Zaino lexicon.

The speaker's state of origin becomes evident, as "research also points out the speaker's location as a differential to explain the variation in his spontaneous speech" (Sá 59), given characteristically southern expressions used, markedly by the supremacy of use of the personal pronoun $t u^{9}$ in practically all the speeches of the characters from Rio Grande do Sul. Still, according to Sá (59), the way of speaking, the accent, the customs "make the speaker's region recognized in any geographical space” (Sá 59).

\section{DIATOPIC VARIATION ISSUES}

The tales analyzed in the article have elements that characterize them as texts with diatopic variation, so it is assessed that, through the analysis of each text, it is possible to identify and understand how south BP performs in comparison with the standard variety of BP. In question, the linguistic variations resulting from the terms dog, horse and man will be privileged in the subsequent analyzes. In the four tables, the outline of the diatopic variants, as well as the standard variants, are highlighted in italics to expose the differences. Some striking lexical distinctions will be listed, for example, without the intention of exhausting the identification of each use.

In view of such Brazil geographic extension, linguistic comparison presented is limited to the state of Rio Grande do Sul and to the BP dictionary form. It is necessary to clarify that the lexical aspect was collected in its entirety from two stories of Contos gauchescos (1976) book, presenting a total of 06 appearances of cusco and 07 of zaino in Trezentas onças, and

\footnotetext{
8 I stuck the horse and rode.

9 You, in English. There are two words for the singular form of you in BP: você and tu. The most common in Brazil is você, but $t u$ is used in some regions of the southern and northern regions.
} 
13 appearances of chiru and 14 of ilhéu in Melancia - Coco verde. Even though this book is full of other diatopic variants which draw attention, it would be quite difficult to analyse the whole book in this paper.

\subsection{Trezentas Onças}

In the short story "Trezentas onças" from the work "Contos Gauchescos", the cowboy Blau Nunes, traveled with a dog that belonged to the children of his boss's farm. He realized that he had lost his bag, with three hundred golden coins, which would be paid for the cattle that were on another farm; that money belonged to his boss, an honest meat seller from the region. Deciding to tell the truth about what happened, he is surprised to see his bag with the three hundred golden coins on the boss's table.

In the short story Trezentas onças, the man is characterized as rude, honest and has values, he cares about his family and his dignity, as noted in "Eu era mui pobre"10" (Lopes Neto 12) and "Eh-pucha! Patrício, eu sou muito rude"11. In both cases, the word using of mui is a variant from Spanish language muy, since the region of Rio Grande do Sul is neighbored by Hispanic countries. It should be noted that the author preferred writing with i over $y$, to locate the word in the Portuguese language, even though the standard word is very, the closest term in English.

In fauna, we can see that the main character is the puppy that is always warning about the trail. According to the Dicionário online, one can also complement that the word cusco is a regional masculine noun that refers to the "small dog, of ordinary breed; guaipé, guaipeca, guapeca, guapeva, jaguapeba ${ }^{12} "$, that is, it would really be the mixed breed dog. In this sense, even the least experienced reader can tie the meaning of cusco to dog by the context in which the word appears. In the short story, there are the following diatopic variations referring to the word dog:

\footnotetext{
${ }^{10}$ I was very poor

11 Eh-pucha! Patrício, I am very rude

12 These words refer to dog.
} 
Table 01 - cusco

\begin{tabular}{|c|c|c|c|}
\hline pp. & Diatopic variant & Standard variety of $P B$ & English \\
\hline 05 & $\begin{array}{l}\text { Ah!...esqueci de dizer- } \\
\text { lhe que andava comigo } \\
\text { um cachorrinho } \\
\text { brasino, um cusco mui } \\
\text { esperto e boa vigia. }\end{array}$ & $\begin{array}{l}\text { Ah!...esqueci de dizer-lhe } \\
\text { que andava comigo um } \\
\text { cachorrinho cor de brasa, } \\
\text { um cão muito esperto e } \\
\text { boa vigia. }\end{array}$ & $\begin{array}{l}\text { Ah!... I forgot to tell you } \\
\text { that a red-hot puppy was } \\
\text { walking with me, a very } \\
\text { smart dog and a good } \\
\text { watchman. }\end{array}$ \\
\hline 05 & $\begin{array}{l}\text { Durante a troteada } \\
\text { bem reparei que volta e } \\
\text { meia o cusco parava-se } \\
\text { na estrada e latia e } \\
\text { corria pra trás, e } \\
\text { olhava-me, olhava-me, } \\
\text { e latia de novo e } \\
\text { troteava um pouco } \\
\text { sobre o rastro. }\end{array}$ & $\begin{array}{l}\text { Durante a trotada bem } \\
\text { reparei que volta e meia o } \\
\text { cachorro parava-se na } \\
\text { estrada e latia e corria pra } \\
\text { trás, e olhava-me, olhava- } \\
\text { me, e latia de novo e } \\
\text { trotava um pouco sobre o } \\
\text { rastro. }\end{array}$ & $\begin{array}{l}\text { During the trot well I } \\
\text { noticed that now and then } \\
\text { the dog would stop on the } \\
\text { road and bark and run } \\
\text { backwards, and look at } \\
\text { me, look at me, and bark } \\
\text { again and trot a little on } \\
\text { the trail. }\end{array}$ \\
\hline 06 & $\begin{array}{l}\text { Nisto o cusco brasino } \\
\text { deu uns pulos ao } \\
\text { focinho do cavalo, } \\
\text { como querendo lambê- } \\
\text { lo, e logo correu para a } \\
\text { estrada, aos latidos. }\end{array}$ & $\begin{array}{l}\text { Nisto o cachorro } \\
\text { vermelho deu uns pulos ao } \\
\text { focinho do cavalo, como } \\
\text { querendo lambê-lo, e logo } \\
\text { correu para a estrada, aos } \\
\text { latidos. }\end{array}$ & $\begin{array}{l}\text { At this, the red dog } \\
\text { jumped the horse's nose, } \\
\text { as if wanting to lick it, and } \\
\text { then ran to the road, } \\
\text { barking. }\end{array}$ \\
\hline 07 & $\begin{array}{l}\text { o cusco encarapitado } \\
\text { na pedra, ao meu lado, } \\
\text { estava me lambendo a } \\
\text { mão. }\end{array}$ & $\begin{array}{l}\text { o cão em cima da pedra, } \\
\text { ao meu lado, estava me } \\
\text { lambendo a mão. }\end{array}$ & $\begin{array}{l}\text { the dog on the rock beside } \\
\text { me was licking my hand. }\end{array}$ \\
\hline 08 & $\begin{array}{l}\text { O cusco escaramuçou, } \\
\text { contente; }\end{array}$ & $\begin{array}{l}\text { O cachorro lutou, } \\
\text { contente; }\end{array}$ & $\begin{array}{l}\text { The dog struggled, } \\
\text { content; }\end{array}$ \\
\hline 09 & $\begin{array}{l}\text { Então fui para dentro: } \\
\text { na porta dei o Louvado } \\
\text { seja Jesu-Cristo; boa- } \\
\text { noite! e entrei, e } \\
\text { comigo, rente o cusco. }\end{array}$ & $\begin{array}{l}\text { Então fui para dentro: na } \\
\text { porta dei o Louvado seja } \\
\text { Jesu-Cristo; boa-noite! e } \\
\text { entrei, e comigo, rente o } \\
\text { cão. }\end{array}$ & $\begin{array}{l}\text { So I went inside: at the } \\
\text { door I gave the Praise be } \\
\text { Jesus Christ; good } \\
\text { evening! and I went in, } \\
\text { and with me, close the } \\
\text { dog. }\end{array}$ \\
\hline
\end{tabular}

Sourse: author's elaboration.

The horse appears in the narrative as freedom and work means. In standard Brazilian Portuguese, there are some synonyms for the masculine noun horse, such as steed, rider and 
horse. Thus, it is understood that the word zaino performs as a diatopic variant for horse and not as a synonym itself. According to the Dictionary online, it can be complemented even though the word zaino is an adjective that refers to "uniform and dark brown-haired horse, without spots or stitches". In the figurative sense, it has been withdrawn or concealed, which comes close to the synonyms miserly and rogue. In etymology, zaino comes from Hispanic Arabic zahim, according to the educalingo website. It is possible that even the reader from other country regions understands the meaning of Zaino masculine noun, in the cases below, as a horse by context, without the necessity to check the dictionary.

Table 02: zaino

\begin{tabular}{|c|c|c|c|}
\hline pp. & Diatopic variant & $\begin{array}{l}\text { Standard variety of } \\
\text { BP }\end{array}$ & English \\
\hline 05 & $\begin{array}{l}\text { E solito e no silêncio, } \\
\text { tornei a vestir-me, } \\
\text { encilhei o zaino e } \\
\text { montei. }\end{array}$ & $\begin{array}{l}\text { E sozinho e no silêncio, } \\
\text { tornei a vestir-me, } \\
\text { encilhei o cavalo e } \\
\text { montei. }\end{array}$ & $\begin{array}{l}\text { And alone and in } \\
\text { silence, I got dressed } \\
\text { again, saddled my } \\
\text { horse and rode. }\end{array}$ \\
\hline 05 & $\begin{array}{l}\text { O zaino era um pingaço } \\
\text { de lei. }\end{array}$ & O cavalo era bom. & The horse was good. \\
\hline 06 & $\begin{array}{l}\text { O zaino atirava o freio } \\
\text { e gemia no compasso } \\
\text { do galope, comendo } \\
\text { caminho. }\end{array}$ & $\begin{array}{l}\text { O cavalo atirava o freio } \\
\text { e gemia no compasso } \\
\text { do galope, comendo } \\
\text { caminho. }\end{array}$ & $\begin{array}{l}\text { The horse threw the } \\
\text { bridle and moaned at } \\
\text { the pace of the gallop, } \\
\text { eating its way. }\end{array}$ \\
\hline 07 & $\begin{array}{l}\text { O zaino respirou forte e } \\
\text { sentou, trocando a } \\
\text { orelha, farejando no } \\
\text { escuro: o bagual tinha } \\
\text { reconhecido o lugar, } \\
\text { estava no passo. }\end{array}$ & $\begin{array}{l}\text { O cavalo respirou forte } \\
\text { e sentou, trocando a } \\
\text { orelha, farejando no } \\
\text { escuro: o domado tinha } \\
\text { reconhecido o lugar, } \\
\text { estava no passo. }\end{array}$ & $\begin{array}{l}\text { The horse took a deep } \\
\text { breath and sat down, } \\
\text { changing his ear, } \\
\text { sniffing in the dark: the } \\
\text { tamer had recognized } \\
\text { the place, he was in } \\
\text { step. }\end{array}$ \\
\hline 07 & $\begin{array}{l}\text { e logo, logo, o zaino } \\
\text { relinchou lá em cima, } \\
\text { na barranca do riacho, } \\
\text { ao mesmíssimo tempo } \\
\text { que a cantoria alegre de } \\
\text { um grilo retinia ali } \\
\text { perto, num oco de } \\
\text { pau!... }\end{array}$ & $\begin{array}{l}\text { e } \operatorname{logo}, \log \text {, o cavalo } \\
\text { relinchou lá em cima, } \\
\text { na barranca do riacho, } \\
\text { ao mesmíssimo tempo } \\
\text { que a cantoria alegre de } \\
\text { um grilo retinia ali } \\
\text { perto, num oco de } \\
\text { pau!... }\end{array}$ & $\begin{array}{l}\text { and soon, soon, the } \\
\text { horse whinnied up } \\
\text { there, in the bank of the } \\
\text { stream, at the same } \\
\text { time that the joyful } \\
\text { singing of a cricket was } \\
\text { ringing nearby, in a } \\
\text { hollow of wood!... }\end{array}$ \\
\hline
\end{tabular}


Artículo. Dayse Rodrigues dos Santos. "The diatopic variants Cusco, Zaino, Chiru and Ilhéu in brazilian portuguese"

\begin{tabular}{|l|l|l|l|}
\hline 07 & $\begin{array}{l}\text { assim que me sentiu o } \\
\text { zaino escarceou, } \\
\text { mastigando o freio. }\end{array}$ & $\begin{array}{l}\text { assim que me sentiu o } \\
\text { cavalo abaixou e e evantou a cabeça, } \\
\text { levas I felt the } \\
\text { mastigando o freio. }\end{array}$ & $\begin{array}{l}\text { as soon as ducked and } \\
\text { horsed its head, } \\
\text { chewing on the bridle. }\end{array}$ \\
\hline 08 & $\begin{array}{l}\text { O zaino relinchou } \\
\text { alegremente, sentindo } \\
\text { os companheiros. }\end{array}$ & $\begin{array}{l}\text { O cavalo relinchou } \\
\text { alegremente, sentindo } \\
\text { os companheiros. }\end{array}$ & $\begin{array}{l}\text { The horse neighed } \\
\text { happily, sensing his } \\
\text { companions. }\end{array}$ \\
\hline
\end{tabular}

Sourse: author's elaboration.

Despite the numerous synonyms for the word cusco, the author repeats the term in a clear attempt to maintain the characteristic of the southern language. It is possible to notice affection when referring to a dog, as it represents a loyal relationship in friendship with the owner. There are no numerous synonyms for the word zaino that come close to the meanings it has in the text. In this story, the most appropriate lexical variant would be the mixed breed horse. In both cases, when using these words to refer to his life and work partners, the narrator ratifies his linguistic relations in the place where he lives.

\subsection{Melancia - Coco Verde}

Costinha was in love with Talapa, but the girl's father did not want to date. To communicate, she would be Watermelon and him Green coconut in the messages. Her father wanted to marry her to a nephew, much to the girl's dismay. On the day of the wedding, Costinha sends a message through his friend Reduzo-Coco Verde sends news to Melancia-, saying that he would be back from the war. The bride passed out and the wedding did not take place. Later, Watermelon and Green Coconut got married and took Reduzo as a trusted foreman.

In the short story "Melancia - Coco verde" we find two different men's types. The native and the foreigner. The native is a brave, strong and warrior man. In the short story, the native is referred to as chiru, a masculine noun that means caboclo or Indian and White's son, because this word expresses the bravery native man, reminiscent people from old Rio Grande do Sul inhabitants. In etymology, the word chiru has its origins in Tupi xeirú, according to the online dictionary website, and "in the Tupi-Guarani language, spoken by the 
South Indians from South America before the arrival of the Portuguese and Spanish", as meanings.

Table 03 - chiru

\begin{tabular}{|c|c|c|c|}
\hline pp. & Diatopic variant & $\begin{array}{c}\text { Standard variety of } \\
\text { BP }\end{array}$ & English \\
\hline 43 & $\begin{array}{l}\text { O chiru criou-se junto } \\
\text { com os meninos. }\end{array}$ & $\begin{array}{l}\text { O caboclo criou-se } \\
\text { junto com os meninos. }\end{array}$ & $\begin{array}{l}\text { The Indian and white's } \\
\text { son was raised along } \\
\text { with the children. }\end{array}$ \\
\hline 43 & $\begin{array}{l}\text { O chiru ficou todo } \\
\text { ganjento. }\end{array}$ & $\begin{array}{l}\text { O caboclo ficou todo } \\
\text { vaidoso. }\end{array}$ & $\begin{array}{l}\text { The Indian and white's } \\
\text { son was all vain. }\end{array}$ \\
\hline 45 & $\begin{array}{l}\text { Encilho? reperguntou o } \\
\text { chiru. }\end{array}$ & $\begin{array}{l}\text { Encilho? reperguntou o } \\
\text { caboclo. }\end{array}$ & $\begin{array}{l}\text { I shrink? replied the } \\
\text { Indian and white's son. }\end{array}$ \\
\hline 46 & $\begin{array}{l}\text { foi nesse berzabum do } \\
\text { entrevero que o } \\
\text { Costinha industriou o } \\
\text { chiru. }\end{array}$ & $\begin{array}{l}\text { foi nesse belzebu do } \\
\text { entrevero que } 0 \\
\text { Costinha industriou } \\
\text { caboclo. }\end{array}$ & $\begin{array}{l}\text { it was in this bezel of } \\
\text { the talkins that } \\
\text { Costinha industrialized } \\
\text { the Indian and white's } \\
\text { son. }\end{array}$ \\
\hline 46 & $\begin{array}{l}\text { E enquanto o chiru se } \\
\text { deitava no pescoço do } \\
\text { cavalo e uma lança de } \\
\text { três pontas } \\
\text { escorregava-lhe por } \\
\text { cima do espinhaço, o } \\
\text { Costinha, com um tiro } \\
\text { de pistola derrubava } \\
\text { um gadelhudo } \\
\text { lanceador }\end{array}$ & $\begin{array}{l}\text { E enquanto o caboclo } \\
\text { se deitava no pescoço } \\
\text { do cavalo e uma lança } \\
\text { de três pontas } \\
\text { escorregava-lhe por } \\
\text { cima do espinhaço, o } \\
\text { Costinha, com um tiro } \\
\text { de pistola derrubava } \\
\text { um guedelhudo } \\
\text { lançador. }\end{array}$ & $\begin{array}{l}\text { And while the Indian } \\
\text { and white's son lay on } \\
\text { the horse's neck and a } \\
\text { three-pointed spear slid } \\
\text { over the ridge, } \\
\text { Costinha, with a pistol } \\
\text { shot, knocked down a } \\
\text { launcher. }\end{array}$ \\
\hline 46 & $\begin{array}{l}\text { Isso disse o chiru e } \\
\text { esporeando o flete } \\
\text { atirou-o contra dois } \\
\text { desalmados que iam } \\
\text { degolar um ferido... } \\
\text { emborcou-os a patadas } \\
\text { e logo gritou ao moço. }\end{array}$ & $\begin{array}{l}\text { Isso disse o caboclo e } \\
\text { esporeando o flete } \\
\text { atirou-o contra dois } \\
\text { desalmados que iam } \\
\text { degolar um ferido... } \\
\text { emborcou-os a patadas } \\
\text { e logo gritou ao moço. }\end{array}$ & $\begin{array}{l}\text { That said the Indian } \\
\text { and white's son and, } \\
\text { spurting the flete, } \\
\text { threw him at two } \\
\text { soulless people who } \\
\text { were going to cut a } \\
\text { wounded man ... he } \\
\text { kicked them upside } \\
\text { down and then shouted } \\
\text { at the boy. }\end{array}$ \\
\hline
\end{tabular}


Artículo. Dayse Rodrigues dos Santos. "The diatopic variants Cusco, Zaino, Chiru and Ilhéu in brazilian portuguese"

\begin{tabular}{|c|c|c|c|}
\hline 47 & $\begin{array}{l}\text { Uê! chiru!... Pois tu } \\
\text { não tinhas ido com o } \\
\text { seu Costinha? }\end{array}$ & $\begin{array}{l}\text { Uê! caboclo!... Pois tu } \\
\text { não tinhas ido com o } \\
\text { seu Costinha? }\end{array}$ & $\begin{array}{l}\text { Huh! Indian and } \\
\text { white's son! ... So you } \\
\text { hadn't gone with Mr. } \\
\text { Costinha? }\end{array}$ \\
\hline 47 & $\begin{array}{l}\text { Quando apeou-se, o } \\
\text { chiru estava de pernas } \\
\text { duras. }\end{array}$ & $\begin{array}{l}\text { Quando apeou-se, o } \\
\text { caboclo estava de } \\
\text { pernas duras. }\end{array}$ & $\begin{array}{l}\text { When he dismounted, } \\
\text { the Indian and white's } \\
\text { son was stiff-legged. }\end{array}$ \\
\hline 47 & $\begin{array}{l}\text { Que é do Reduzo? Oh! } \\
\text { Chiru?... }\end{array}$ & $\begin{array}{l}\text { Que é do Reduzo? Oh! } \\
\text { Caboclo?... }\end{array}$ & $\begin{array}{l}\text { What about Reduzo? } \\
\text { Oh! Indian and white's } \\
\text { son? ... }\end{array}$ \\
\hline 47 & $\begin{array}{l}\text { E amontoando-se para } \\
\text { a mesa, bem junto dos } \\
\text { que estavam sentados, } \\
\text { frente a frente dos } \\
\text { noivos, olhando pra sia } \\
\text { Talapa o chiru levantou } \\
\text { o copo e disse. }\end{array}$ & $\begin{array}{l}\text { E amontoando-se para } \\
\text { a mesa, bem junto dos } \\
\text { que estavam sentados, } \\
\text { frente a frente dos } \\
\text { noivos, olhando pra sia } \\
\text { Talapa o caboclo } \\
\text { levantou o copo e disse. }\end{array}$ & $\begin{array}{l}\text { And huddling to the } \\
\text { table, right next to } \\
\text { those who were sitting, } \\
\text { facing each other, } \\
\text { looking at Asia Talapa, } \\
\text { the Indian and white's } \\
\text { son raised his glass and } \\
\text { said. }\end{array}$ \\
\hline 47 & $\begin{array}{l}\text { gostei, chiru! outra } \\
\text { vez! }\end{array}$ & $\begin{array}{l}\text { gostei, caboclo! outra } \\
\text { vez! }\end{array}$ & $\begin{array}{l}\text { I liked it, Indian and } \\
\text { white's son! again! }\end{array}$ \\
\hline 48 & $\begin{array}{l}\text { Um que estava perto do } \\
\text { chiru gritou-lhe na } \\
\text { cara. }\end{array}$ & $\begin{array}{l}\text { Um que estava perto do } \\
\text { caboclo gritou-lhe na } \\
\text { cara. }\end{array}$ & $\begin{array}{l}\text { One who was close to } \\
\text { the Indian and white's } \\
\text { son shouted at him. }\end{array}$ \\
\hline 48 & $\begin{array}{l}\text { Tempos depois do } \\
\text { Costinha já casado, } \\
\text { então o chiru tomou } \\
\text { conta dum posto. }\end{array}$ & $\begin{array}{l}\text { Tempos depois do } \\
\text { Costinha já casado, } \\
\text { então o caboclo tomou } \\
\text { conta dum posto. }\end{array}$ & $\begin{array}{l}\text { Times after Costinha } \\
\text { was already married, } \\
\text { then the Indian and } \\
\text { white's son took over a } \\
\text { post. }\end{array}$ \\
\hline
\end{tabular}

Sourse: author's elaboration.

The foreign man is viewed with suspicion by the native men. In this case, the lexical option was the word ilhéu. According to the Dicionário online website, it is an adjective "relative to islands" and its synonym would be island or islet. In its etymology, ilhéu would be the sum "of island + éu or of Old French Isleau", according to the Meu Dicionário website. In this case, the interpretation would be more to the metaphor of the isolated and distant man, that is, to the foreigner of whom one speaks or, still, to insular, to segregate. Also, the diatopic identification about the use of the ilhéu variant is linked to the foreigner insular character. It 
should be noted that the foreigner would not necessarily be the man from abroad, but any outsider or person who is not a native of Brazilian southlands.

Table 04 - ilhéu

\begin{tabular}{|c|c|c|c|}
\hline pp. & Diatopic variant & $\begin{array}{c}\text { Standard variety of } \\
\text { BP }\end{array}$ & English \\
\hline 44 & $\begin{array}{l}\text { Esse tal era um ilhéu, mui } \\
\text { comedor de verduras, e } \\
\text { que para montar a cavalo } \\
\text { havia de ser em petiço e } \\
\text { isso mesmo o petiço } \\
\text { havia de ser podre de } \\
\text { manso }\end{array}$ & $\begin{array}{l}\text { Esse tal era um } \\
\text { segregado, muito } \\
\text { comedor de verduras, e } \\
\text { que para montar a } \\
\text { cavalo havia de ser em } \\
\text { corcel e isso mesmo o } \\
\text { corcel havia de ser } \\
\text { podre de manso. }\end{array}$ & $\begin{array}{l}\text { This guy was a } \\
\text { segregate, very } \\
\text { vegetable eater, and } \\
\text { that to ride a horse it } \\
\text { had to be on a steed } \\
\text { and that same steed } \\
\text { had to be rotten tame }\end{array}$ \\
\hline 44 & $\begin{array}{l}\text { casar uma brasileira } \\
\text { mimosa com um pé-de- } \\
\text { chumbo, como aquele } \\
\text { desgraçado daquele } \\
\text { ilhéu... }\end{array}$ & $\begin{array}{l}\text { casar uma brasileira } \\
\text { mimosa com um pé-de- } \\
\text { chumbo, como aquele } \\
\text { desgraçado daquele } \\
\text { segregado... }\end{array}$ & $\begin{array}{l}\text { marry a mimosa } \\
\text { Brazilian with a lead- } \\
\text { foot, like that bastard } \\
\text { of that segregated... }\end{array}$ \\
\hline 44 & $\begin{array}{l}\text { O ilhéu às vezes vinha à } \\
\text { estância do tio, em } \\
\text { carretinha... }\end{array}$ & $\begin{array}{l}\text { O segregado às vezes } \\
\text { vinha à estância do tio, } \\
\text { em carretinha... }\end{array}$ & $\begin{array}{l}\text { The segregated } \\
\text { sometimes came to } \\
\text { the uncle's office, in a } \\
\text { cart ... }\end{array}$ \\
\hline 44 & $\begin{array}{l}\text { tudo isso, que é do bom. e } \\
\text { do melhor, para o ilhéu } \\
\text { não valia nem um } \\
\text { sabugo!... }\end{array}$ & $\begin{array}{l}\text { tudo isso, que é do } \\
\text { bom. e do melhor, para } \\
\text { o segregado não valia } \\
\text { nem um sabugo!... }\end{array}$ & $\begin{array}{l}\text { all of that, which is } \\
\text { good. and the best, for } \\
\text { the segregated it was } \\
\text { not worth even a cob! } \\
\text {.. }\end{array}$ \\
\hline 44 & Com o ilhéu é que nunca! & $\begin{array}{l}\text { Com o segregado é que } \\
\text { nunca! }\end{array}$ & $\begin{array}{l}\text { With the segregated it } \\
\text { is never! }\end{array}$ \\
\hline 45 & $\begin{array}{l}\text { daí a uns dias o ilhéu batia } \\
\text { na estância, de carretinha } \\
\text { e com um carregamento } \\
\text { de cousas. }\end{array}$ & $\begin{array}{lr}\text { daí a uns dias } & \text { o } \\
\text { segregado batia na } \\
\text { estância, de carretinha } \\
\text { e com } & \text { um } \\
\text { carregamento } & \text { de } \\
\text { coisas. }\end{array}$ & $\begin{array}{l}\text { in a few days the } \\
\text { segregate would hit } \\
\text { the ranch, with a } \\
\text { trailer and a load of } \\
\text { things. }\end{array}$ \\
\hline 45 & $\begin{array}{l}\text { a achar até bonito o } \\
\text { ilhéu... }\end{array}$ & $\begin{array}{l}\text { a achar até bonito o } \\
\text { segregado... }\end{array}$ & $\begin{array}{l}\text { to find the segregated } \\
\text { even beautiful... }\end{array}$ \\
\hline
\end{tabular}




\begin{tabular}{|c|c|c|c|}
\hline 45 & $\begin{array}{l}\text { enquanto mudava de } \\
\text { cavalo tinhaido tomar um } \\
\text { refresco no negócio do } \\
\text { ilhéu. }\end{array}$ & $\begin{array}{l}\text { enquanto mudava de } \\
\text { cavalo tinha ido tomar } \\
\text { um refresco no negócio } \\
\text { do segregado. }\end{array}$ & $\begin{array}{l}\text { while changing } \\
\text { horses he had gone } \\
\text { for a drink in the } \\
\text { segregated business. }\end{array}$ \\
\hline 46 & $\begin{array}{l}\text { A Talapa, depois } \\
\text { d'amanhã, de noite, se } \\
\text { casa, à força, com o ilhéu. }\end{array}$ & $\begin{array}{l}\text { A Talapa, depois } \\
\text { d'amanhã, de noite, se } \\
\text { casa, à força, com o } \\
\text { segregado. }\end{array}$ & $\begin{array}{l}\text { Talapa, after } \\
\text { tomorrow, at night, } \\
\text { forcibly marries the } \\
\text { segregated. }\end{array}$ \\
\hline 47 & $\begin{array}{l}\text { O ilhéu é que estava } \\
\text { solto!... }\end{array}$ & $\begin{array}{l}\text { O segregado é que } \\
\text { estava solto!... }\end{array}$ & $\begin{array}{l}\text { It was the segregate } \\
\text { that was loose! ... }\end{array}$ \\
\hline 47 & $\begin{array}{l}\text { enquanto o ilhéu se } \\
\text { arreganhava numa } \\
\text { gargalhada gostosa }\end{array}$ & $\begin{array}{l}\text { enquanto o segregado } \\
\text { se arreganhava numa } \\
\text { gargalhada gostosa }\end{array}$ & $\begin{array}{l}\text { while the segregated } \\
\text { grinned in a delicious } \\
\text { laugh }\end{array}$ \\
\hline 48 & $\begin{array}{l}\text { O ilhéu olhou para o } \\
\text { Reduzo, viu-lhe o facão } \\
\text { atravessado... }\end{array}$ & $\begin{array}{l}\text { O segregado olhou } \\
\text { para o Reduzo, viu-lhe } \\
\text { o facão atravessado... }\end{array}$ & $\begin{array}{l}\text { The segregated } \\
\text { looked at the Reduzo, } \\
\text { saw the machete } \\
\text { through ... }\end{array}$ \\
\hline 48 & $\begin{array}{l}\text { O ilhéu, do outro lado da } \\
\text { mesa sampou-lhe com } \\
\text { uma botija de bebida, que } \\
\text { acertou bem entre o } \\
\text { queixo e o ouvido do } \\
\text { chiru... }\end{array}$ & $\begin{array}{l}\text { O segregado, do outro } \\
\text { lado da mesa } \\
\text { arremessou-lhe com } \\
\text { uma botija de bebida, } \\
\text { que acertou bem entre o } \\
\text { queixo e o ouvido do } \\
\text { caboclo... }\end{array}$ & $\begin{array}{l}\text { The segregate, on the } \\
\text { other side of the table, } \\
\text { hurled him with a } \\
\text { bottle of drink, which } \\
\text { hit him well between } \\
\text { the caboclo's chin and } \\
\text { ear... }\end{array}$ \\
\hline 48 & $\begin{array}{l}\text { dar uma volta na traira e } \\
\text { reiunar o ilhéu... }\end{array}$ & $\begin{array}{l}\text { dar uma volta na traira } \\
\text { e reiunar o } \\
\text { segregado... }\end{array}$ & $\begin{array}{l}\text { take a turn on the } \\
\text { traira and reign the } \\
\text { segregated ... }\end{array}$ \\
\hline
\end{tabular}

Sourse: author's elaboration.

It is observed in cusco, zaino, chiru and ilhéu occurrences details the possibility of meanings assimilation through the context. However, the reader who searches for them in Portuguese online dictionaries will hardly find the reference to the regionalist character of such terms. Thus, although the meaning of these words is known, it becomes complex for the less experienced readers to note that it is a diatopic variant and not synonymy properly. In Brayna Cardoso (16) studies on diatopic variation in school dictionaries, it can be observed 
that failure to mention the geographic framework of the terms may compromise the diatopic characteristics of the terms.

if the querent when searching a dictionary knows only one entry and the dictionary does not provide the other variants, then the querent will not find what he searches for and consequently will not know the use of that lexia in other geographic spaces (Cardoso 90).

Thus, there is a need to realize that these terms are, in fact, diatopic varieties of dog, horse, foreigner and Indian and white's son. In general, monolingual and bilingual dictionaries hardly explain that these meanings are geographic variation. Thus, these four southern variants studies using can point to the hypothesis about the processes of occupation influences, settlement and language interactions with neighbors Argentina and Uruguay, observed in Brazil's south.

According to these four lexical item occurrences, whether morphological or semantic, one can speak of socio-dialectal variants and not just dialectal ones, as the short stories emphasize these types of variants to mark writing and literary subgenre style. Hence, these terms, cusco, zaino, chiru an ilhéu, were privileged despite cachorro, cavalo, caboclo e forasteiro, most used in the rest of the country's speech. This is possible because south Brazilians have been using these terms for many years until nowadays.

The lexic is still common in day-by-day language in Rio Grande do Sul BR, but it is necessary to say that this author is widely known as a cultural conserver. It does not mean that he forces a specific communicative situation, but he uses the literature language to give poetry to his texts. Other writers or even artists also use these techniques to maintain southern characteristics alive in gaúchos ' lives, as Érico Verissimo (1905-1975), Jaime Caetano Braun (1924-1999), Cyro Martins (1908-1995), Alcione Sortica (1935-), Luis Antonio de Assis Brasil (1945-), Tabajara Ruas (1942-) among other who dedicated their lives to literature.

\section{Conclusion}

Sociolinguistics studies the language in society, both in its expression of speech and in writing. In this sense, this analysis of literary texts with a strong folklore particularities Trezentas onças e Melancia - Coco verde, by Simões Lopes Neto, addressed common aspects 
of southern Brazil language present in the lexicon at the end of the 19th and 20th century. The literary work in question is a very rich source for sociolinguistic and / or dialectological studies and research, as its vocabulary repertoire is invaluable for Brazilian culture. The linguistic variation found in the corpus could be analyzed from the concepts of Ronald Beline (2003), Edimilson Sá (2009) and Valter Romano (2014), who affirm that language is not an isolated factor, that it manifests itself according to regional and social conditions in general. This study provided a theoretical dialectical detail of four variants present in BP, cusco, zaino, chiru and ilhéu as it was proposed at the beginning. Such words express references from the southern region, the people, their customs, their speech and their values; through this literary work. Knowing these aspects and rescuing them is an object of study in sociolinguistics, in which it rescues and analyzes language in its social relations, and in dialectology, which analyzes regional lexical items at its different levels. This way, it can be considered that lexical items cusco, zaino, chiru and ilhéu in fact converge as variants of dog, horse, Indian's son and foreigner as it is possible to write in English or Brazilian Portuguese standards.

In this respect, the two tales converge on the diatopic variation treatment, both show the repeated use of the southern terms to mark the geographical setting, that is, they ratify the same words. It should be noted, however, that the words cusco, zaino, chiru and ilhéu were used with supremacy, but not exclusively, because, throughout the stories, there are other nouns and adjectives acting as synonyms. Furthermore, these expressions are not peculiar to one or another character from the tales analysed, as it was studied in this article.

Main variants rescued in the two stories made it possible to verify the introduction of the items in the Portuguese language as well as to compare different contexts of use. In this case, it is notable to say that the lexic is not used nowadays as it was used in the authors' period or even earlier twenties. In addition, the influences of other languages in the process of forming Portuguese became evident, such as the case of Cusco, Castilian, Zaino, Arabic, Ilhéu, French and Chiru, Tupi, which means the language's heterogeneity.

It is also possible to observe the arduous task of translating these words into the language used to write this article, in order to preserve the meaning and the representative language southern characteristics. It is a consensus in this research area that the translation does not necessarily have to be faithful to the original text, however it was used as an 
illustrative resource in order to assist the reader in building his own perceptions of meaning about the diatopic variation in relation to the standard language, i.e., significant differences between the two variety of Brazilian Portuguese.

Portuguese language description in its diatopic variants, at the lexical level is an urgent task, in order to have a reliable Portuguese language representation in Brazil. This article does not end the discussion on diatopic variation in Brazilian short stories, on the contrary, it seeks to stimulate an increase in the study and debate about the dialects present in the language. Thus, when understanding the main linguistic variants present in this work by João Simões Lopes Neto, there is a possibility of deepening the particularities of these lexicons prevalent in the state of Rio Grande do Sul, Brazil's southern.

\section{REFERENCES}

Aragão, Maria do Socorro Silva de. "Variantes diatópicas e diastráticas na língua portuguesa do Brasil". Graphos, num 2, 2010, pp. 1516-1536.

Beline, Ronald. "Variação lingüística". Introdução à Lingüística - I. Objetos teóricos, Edited by José Luís Fiorin. Contexto, 2002, pp. 121-140.

Cardoso, Brayna Conceição dos Santos. "A variação diatópica no dicionário escolar”. Edited by Raimunda Benedita Cristina Caldas, Larissa Fontinele de Alencar e Fernando Alves da Silva Júnior. Inclusão e preservação de saberes para o bom viver. Pedro \& João Editores, 2016, pp. 81-97.

Lopes Neto, João Simões. Contos gauchescos. 9ª ed., Porto Alegre: Globo, 1976.

Pereira, Luis Artur Borges. Aspectos das diversas manifestações do projeto cívicopedagógico de João Simões Lopes Neto. Pelotas, 2008, pp. 261. Thesis (Master's degree) - Universidade Federal de Pelotas.

Romano, Valter Pereira; Rodrigo Duarte Seabra. "Dados geolinguísticos sob uma perspectiva estatística: a variação lexical no Centro-Oeste, Sudeste e Sul do Brasil". Estudos da linguagem, num. 2, 2014 pp. 59-92.

Romano, Valter Pereira. Em busca de falares a partir de áreas lexicais no Centro-Sul do Brasil. 2015. 2v. Thesis (PhD in Language Studies) - Universidade Estadual de Londrina, Londrina. Volume1: pp. 296. Volume 2: Uma carta introdutória, 71 cartas linguísticas e 10 relatórios.

Sá, Edmilson José de. Língua e Sociedade. Conhecimento prático da Língua Portuguesa, São Paulo, Escala Educacional, nº 16, 2009. 
Artículo. Dayse Rodrigues dos Santos. "The diatopic variants Cusco, Zaino, Chiru and Ilhéu in brazilian portuguese"

Teixeira, José. "Modelos Semânticos e Variação Diatópica". I Encontro de Estudos Dialectológicos - Actas. Edited by Maria Clara Rolão Bernardo and Helena Mateus Montenegro. Ponta Delgada, 2006, pp- 363-380.

Dicio. "Dicionário online de português", https://www.dicio.com.br/. Accessed on February, 102021.

Educalingo. "Dicionário de espanhol", https://educalingo.com/pt/dic-es/zaino. Accessed on February, 112021.

Significados. "Dicionário", https://www.significados.com.br/xiru. Accessed on February, 112021. 